\title{
The Cardiovascular Effects of Central Hydrogen Sulfide Are Related to $K_{\mathrm{ATP}}$ Channels Activation
}

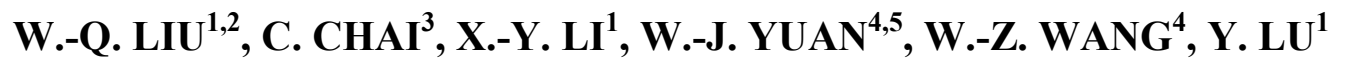 \\ ${ }^{1}$ Department of Clinical Laboratory, San Ai Tang Hospital, Lanzhou, China, ${ }^{2}$ Department of Anus \\ and Intestine Surgery, Daxing Hospital Affiliated to Capital Medical University, Beijing, China, \\ ${ }^{3}$ Department of General Surgery, First Hospital of Lanzhou University, Lanzhou, China, \\ ${ }^{4}$ Department of Physiology, Second Military Medical University, Shanghai, China, ${ }^{5}$ Department of \\ Physiology, Ningxia Medical University, YinChuan, China
}

Received October 3, 2010

Accepted May 5, 2011

On-line August 1, 2011

\section{Summary}

Hydrogen sulfide $\left(\mathrm{H}_{2} \mathrm{~S}\right)$, an endogenous "gasotransmitter", exists in the central nervous system. However, the central cardiovascular effects of endogenous $\mathrm{H}_{2} \mathrm{~S}$ are not fully determined. The present study was designed to investigate the central cardiovascular effects and its possible mechanism in anesthetized rats. Intracerebroventricular (icv) injection of NaHS $(0.17 \sim 17 \mu \mathrm{g})$ produced a significant and dose-dependent decrease in blood pressure (BP) and heart rate (HR) $(P<0.05)$ compared to control. The higher dose of NaHS $(17 \mu \mathrm{g}, \mathrm{n}=6)$ decreased BP and HR quickly of rats and 2 of them died of respiratory paralyse. Icv injection of the cystathionine betasynthetase (CBS) activator s-adenosyl-L-methionine (SAM, $26 \mu \mathrm{g}$ ) also produced a significant hypotension and bradycardia, which were similar to the results of icv injection of NaHS. Furthermore, the hypotension and bradycardia induced by icv $\mathrm{NaHS}$ were effectively attenuated by pretreatment with the $\mathrm{K}_{\text {ATP }}$ channel blocker glibenclamide but not with the CBS inhibitor hydroxylamine. The present study suggests that icv injection of NaHS produces hypotension and bradycardia, which is dependent on the $\mathrm{K}_{\text {ATP }}$ channel activation.

\section{Key words}

Rat $\bullet$ Hydrogen sulfide $\bullet$ Blood pressure $\bullet$ Heart rate $\bullet$ Central

\section{Corresponding authors}

Yan Lu, Department of Clinical Laboratory, San Ai Tang Hospital, 74 Jing-Ning Road, Lanzhou 730030, China. Fax: +86-9318451146. E-mail: lu73free@yahoo.com.cn and

Wei-Zhong Wang, Department of Physiology, Second Military Medical University, 800 Xiang-Yin Road, Shanghai 200433, China. E-mail: wangwz68@hotmail.com

\section{Introduction}

Hydrogen sulfide $\left(\mathrm{H}_{2} \mathrm{~S}\right)$, which was originally considered as a toxic gas with the smell of rotten eggs (Reiffenstein et al. 1992, Beauchamp et al. 1984), has been found in most of tissues in mammalian and produces profound influences on nervous system (Eto et al. 2002, Kimura 2002), vascular (Beltowski 2004, Tang et al. 2005), and gastrointestinal smooth muscles (Teague et al. 2002, Gallego et al. 2008). It has been demonstrated that endogenous $\mathrm{H}_{2} \mathrm{~S}$ is produced from L-cysteine metabolism mainly by cystathionine beta-synthetase (CBS), cystathionine gamma-lyase (CSE), or 3-mercaptosulfur-transferase (MST) (Lowicka and Beltowski 2007, Yang et al. 2005). The vascular $\mathrm{H}_{2} \mathrm{~S}$ is mostly generated by CSE, while the central $\mathrm{H}_{2} \mathrm{~S}$ including brainstem is mainly produced by CBS from cysteine (Hosoki et al. 1997, Abe and Kimura 1996). The brainstem containing cardiovascular centers displays the greatest uptake of sulfide (Warenycia et al. 1989). Previous studies show that $\mathrm{H}_{2} \mathrm{~S}$ modulates vasodilatation by endothelium-dependent (Distrutti et al. 2006) and endothelium-independent mechanism (Wang 2002), but also regulates neuronal functions in the CNS, including the induction of hippocampal long-term potentiation 
(Hosoki et al. 1997, Abe and Kimura 1996, Eto et al. 2002) and the release of the corticotrophin-releasing hormone from the hypothalamus (Lowicka and Beltowski 2007, Boehning and Snyder 2003, Wang 2002). Therefore, $\mathrm{H}_{2} \mathrm{~S}$ has been proposed to be an endogenous "gasotransmitter" besides nitric oxide (NO) and carbon monoxide (CO) (Wang 2003, Laggner et al. 2007, Chen et al. 2007).

It has been found that $\mathrm{H}_{2} \mathrm{~S}$ contributes to cardiovascular regulation. For example, intravenous injection of $\mathrm{H}_{2} \mathrm{~S}$ induces a transient hypotension in anesthetized rats, which can be mimicked by the $\mathrm{K}_{\mathrm{ATP}}$ channel opener pinacidil and effectively antagonized by the $\mathrm{K}_{\mathrm{ATP}}$ channel blocker glibenclamide (Wang 2002, Zhao et al. 2001). In vitro, $\mathrm{H}_{2} \mathrm{~S}$ can relax aortic tissue or hyperpolarize membrane in isolated vascular smooth muscle cells (VSMC) (Tang et al. 2005, Wang 2002). In the central nervous system (CNS), $\mathrm{H}_{2} \mathrm{~S}$ induces a hyperpolarization and reduces an input resistance of CA1 neurons or dorsal raphe neurons in $\mathrm{K}_{\mathrm{ATP}}$ channelsdependant manner (Reiffenstein et al. 1992). Recently, Dawe et al. (2008) report that microinjection of NaHS into the hypothalamus reduces BP and HR in rats, which could be effectively antagonized by prior application of the $\mathrm{K}_{\mathrm{ATP}}$ channel blocker gliclazide. In the waked Wistar Kyoto rats, however, intracerebroventricular (icv) injection of NaHS produces a significant pressor effect (Ufnal et al. 2008). It is not clear whether this cardiovascular effect of icv $\mathrm{H}_{2} \mathrm{~S}$ is dependent on the $\mathrm{K}_{\text {ATP }}$ channel activation. Hence, in the present study, the main aim was to determine the relationship between the central effect of $\mathrm{H}_{2} \mathrm{~S}$ and the functional state of the $\mathrm{K}_{\text {АTP }}$ channel.

\section{Materials and Methods}

\section{General procedure}

Male Sprague-Dawley (SD) rats (weighing 200 to $250 \mathrm{~g}$ ) were employed in this study. Each animal experimentation was in accordance with the Guide for the Care and Use of Laboratory Animals (1985), NIH, Bethesda, or European Guidelines on Laboratory Animal Care. The methods for animal preparation, icv injection and histological procedures were similar to those described previously (Lu et al. 2005, Lu et al. 2007). In brief, rats were anesthetized with urethane (1.3 g/ $\mathrm{kg}$, i.p.). For direct measurement of BP, a catheter was inserted into the right femoral artery. BP was sequentially measured and displayed on a channel of a recording system (XJH, 2007, China) by a computer and HR was computed from the BP waveforms and displayed on another channel of the recording system. BP and HR were recorded continuously. Another catheter was inserted into right femoral vein for drug administration. Following tracheotomy, 30 rats (for determination of dose-dependent effects of NaHS or SAM) were spontaneously ventilated. The other rats (pretreatment with hydroxylamine, glibenclamide or vehicle) were paralyzed with triethiodide $(10 \mathrm{mg} / \mathrm{kg}$ initially and $4 \mathrm{mg} / \mathrm{kg}$ every $30 \mathrm{~min}$, i.v.) and artificially ventilated with oxygen-enriched room air. Adequacy of anesthesia was assessed by monitoring the stability of BP, and BP response to noxious stimulation. Body temperature was maintained at about $37^{\circ} \mathrm{C}$ with an infrared heating lamp.

\section{Icv injection}

The rats were fixed on a stereotaxic frame (MP8003, China) and received a limited craniotomy. Icv injection was performed by a microsyringe $(5 \mu \mathrm{l})$. The stereotaxic coordinates of lateral cerebral ventricle (LCV) were determined according to the Paxinos and Watson rat atlas $(1.0 \mathrm{~mm}$ lateral to medial line, $1.5 \mathrm{~mm}$ caudal to bregma, and $4.5 \mathrm{~mm}$ deep from the bone surface). All chemicals were obtained from Sigma Corporation (America). NaHS, hydroxylamine and SAM was dissolved in artificial cerebrospinal fluid (aCSF, in $\mathrm{mM}$ : 133.3 NaCl, $\quad 3.4 \mathrm{KCl}, \quad 1.3 \mathrm{CaCl}_{2}, \quad 1.2 \mathrm{MgCl}_{2}$, $0.6 \mathrm{NaH}_{2} \mathrm{PO}_{4}, 32.0 \mathrm{NaHCO}_{3}$, and 3.4 glucose, $\mathrm{pH}$ to 7.4 by $0.5 \mathrm{M}$ hydrochloric acid). The NaHS solution was strictly temporary prepared in an enclosed vital before microinjection, which made NaHS solution less dissociated. Glibenclamide was initially dissolved in dimethysulfoxide (DMSO) and diluted with aCSF to the final concentration (the final percentage of DMSO in aCSF is not more than $1 \%$ ). The dose of NaHS, SAM, HA and glibenclamide was based on our preliminary experiment and previous studies (Dawe et al. 2008, Nishimura et al. 1995b, Nishimura et al. 1995a, Lin et al. 1999). The volume of drug injection was $5 \mu \mathrm{l}$, and delivered over a period of approximately $30 \mathrm{~s}$. At the end of each experiment, $5 \mu \mathrm{l}$ of $2 \%$ Pontamine sky blue solution was injected into LCV to identify the injection area. The brain was removed and sectioned to determine the injection area. Histological examination revealed that the dye was correctly injected into the LCV in all experimental rats.

\section{Experimental protocol}

First, NaHS (0.17-17 $\mu \mathrm{g})$, a donor of $\mathrm{H}_{2} \mathrm{~S}$, was 
injected into LCV in 19 rats to observe the dosedependent effects of central $\mathrm{H}_{2} \mathrm{~S}$. In another 7 rats, the cardiovascular functions of central NaHS were determined by increased the concentration of endogenous $\mathrm{H}_{2} \mathrm{~S}$ by icv application of the allosteric CBS activator SAM $(26 \mu \mathrm{g})$. ACSF $(5 \mu \mathrm{l})$ was injected (icv) in 4 rats as control. The responses to icv injection of NaHS, SAM, or aCSF were followed at least 1 hour. HA $(n=7)$, an inhibitor of CBS, was prior respectively applied into LCV of rats, and NaHS $(1.7 \mu \mathrm{g})$ was injected after $10 \mathrm{~min}, \mathrm{BP}$ and HR response was followed at least 1 hour after NaHS injection to observe the $\mathrm{H}_{2} \mathrm{~S}$ central cardiovascular responses after CBS was inhibited. Furthermore, to determine whether the cardiovascular effects of central $\mathrm{H}_{2} \mathrm{~S}$ was mediated by $\mathrm{K}_{\text {ATP }}$ channels $(\mathrm{n}=7)$, the $\mathrm{K}_{\text {ATP }}$ channel blocker glibenclamide was prior icv injected, and NaHS (1.7 $\mu \mathrm{g})$ was centrally applied after $10 \mathrm{~min}$. The mixed solution of aCSF and DMSO (100:1, n=4) was applied as vehicle group.

\section{Statistical analysis}

All values are presented as mean $\pm \mathrm{SE}$. The magnitudes of the changes in mean arterial pressure (MAP) and HR at the different times after injection of agents were compared with a one-way repeated-measures ANOVA followed with the Newman-Keuls test for post hoc analysis was used when multiple comparisons were made. Pre- vs. post-injection comparisons in same animal were evaluated by Student's t-test. The criterion for statistical significance was set at $P<0.05$.
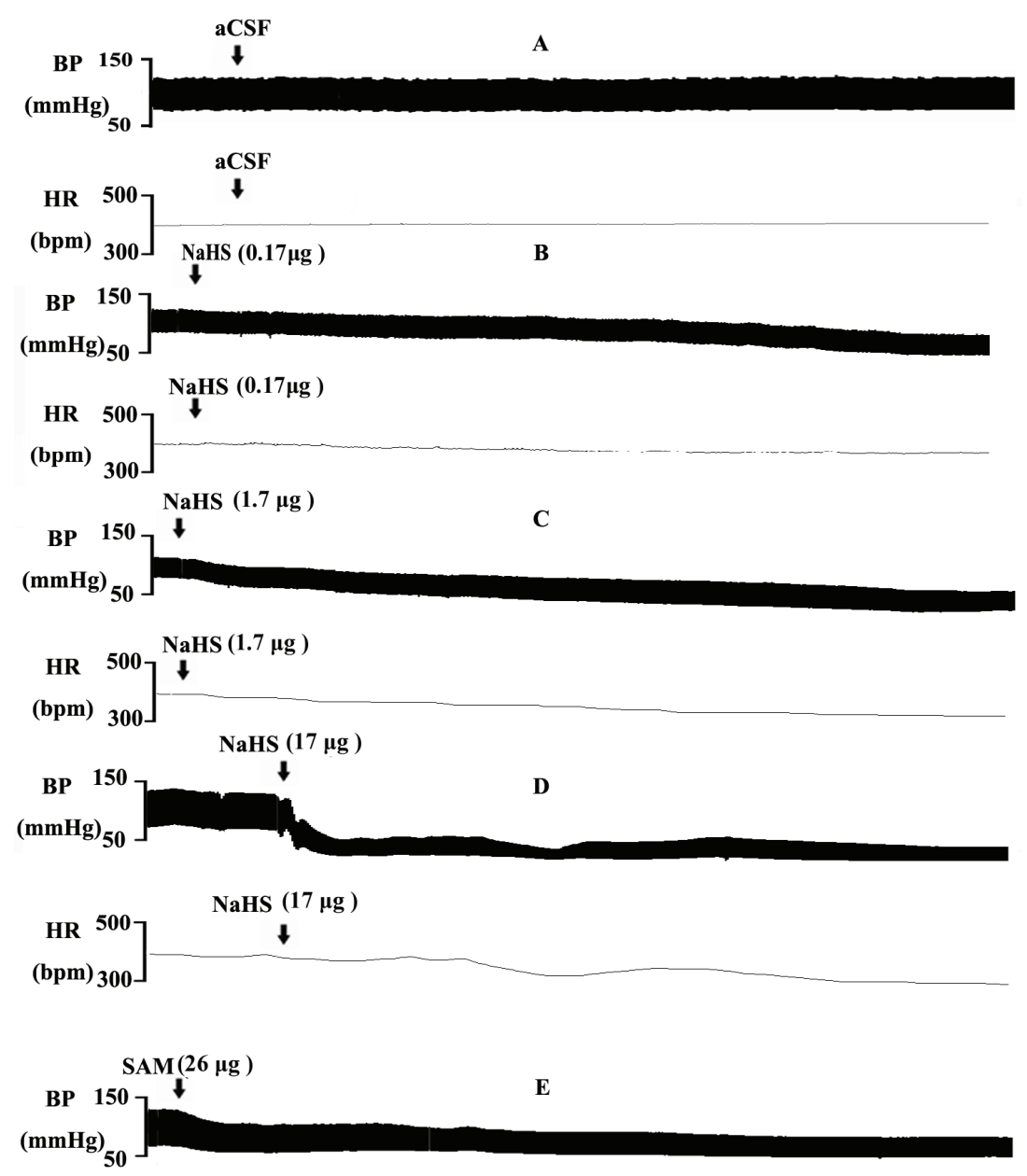

\footnotetext{
$\left.\begin{array}{cc} & \operatorname{SAM}(26 \mu \mathrm{g}) \\ \text { HR }^{500} & \\ \text { (bpm) } & 300\end{array}\right]$
}

Fig. 1. The representative tracings showing the effects of injection (icv) of artificial cerebrospinal fluid (aCSF, $5 \mu \mathrm{l}$ A), hydrogen sulfide (NaHS, $0.17 \sim 17 \mu \mathrm{g}$, B-D) or S-adenosyl-Lmethionine (SAM, $26 \mu \mathrm{g}, \mathbf{E}$ ) on the blood pressure (BP) and heart rate (HR) response. The arrow point indicated the time point of icv injection of aCSF, NaHS or SAM. 


\section{Results}

\section{Effects of icv injection of NaHS or SAM on BP and HR}

Fig. 1 presented the representative original tracings of $\mathrm{BP}$ and $\mathrm{HR}$ in response to icv injection of NaHS $(0.17 \sim 17 \mu \mathrm{g})$, SAM $(26 \mu \mathrm{g})$ or aCSF. Injection of aCSF did not change MAP $(96 \pm 5$ vs. $94 \pm 4 \mathrm{mmHg}$, $P>0.05, \mathrm{n}=4)$ and HR $[481 \pm 30$ vs. $461 \pm 43$ beats per min (bpm), $P>0.05, \mathrm{n}=5]$. Central application of NaHS $(0.17 \sim 17 \mu \mathrm{g})$ produced a significant and dose-dependent decrease in BP $(0.17 \mu \mathrm{g}$ : from $92 \pm 4$ to $67 \pm 7 \mathrm{mmHg}, \mathrm{n}=7$; $1.7 \mu \mathrm{g}$ : from $89 \pm 4$ to $49 \pm 4 \mathrm{mmHg}, \mathrm{P}<0.05, \mathrm{n}=6)$ and $\mathrm{HR}$ (0.17 $\mu \mathrm{g}$ : from $440 \pm 8$ to $382 \pm 8 \mathrm{bpm}, \mathrm{P}<0.05, \mathrm{n}=7$; $1.7 \mu \mathrm{g}$ : from $449 \pm 8$ to $376 \pm 16 \mathrm{bpm}, \mathrm{P}<0.05, \mathrm{n}=6)$. The hypotension and bradycardia occurred $5 \mathrm{~min}$ after administration of NaHS, followed by a sustained decrease, and reached the nadir after $40 \mathrm{~min}$. BP and HR didn't return to the baseline levels within $60 \mathrm{~min}$. Icv injection of NaHS (17 $\mu \mathrm{g}, \mathrm{n}=4)$ produced rapidly hypotension (from $97 \pm 2$ to $57 \pm 9 \mathrm{mmHg}, \mathrm{P}<0.05$ ) and bradycardia (from $415 \pm 14$ to $368 \pm 24 \mathrm{bpm}, \mathrm{P}<0.05, \mathrm{n}=5$ ). In 6 rats, 2 of them died of respiratory paralysis within 15 min because of no artificial ventilation promptly. The central cardiovascular effects of endogenous $\mathrm{H}_{2} \mathrm{~S}$ were further determined by application of SAM, an activator of CBS, into LCV of rats. Icv injection of SAM (26 $\mu \mathrm{g}$, $\mathrm{n}=7$ ) elicited a significant decrease in BP and HR, which was similar to those of icv NaHS. The hypotension (from $94 \pm 6$ to $71 \pm 10 \mathrm{mmHg}, \mathrm{n}=8, P<0.05)$ and bradycardia (from $444 \pm 35$ to $385 \pm 64 \mathrm{bmp}, \mathrm{n}=7, P<0.05$ ) induced by icv injection of SAM also occurred $5 \mathrm{~min}$ after administration, followed a sustained decrease in BP and $\mathrm{HR}$, and didn't return to baseline within $60 \mathrm{~min}$. The changes in MAP and HR in response to icv injection of NaHS or SAM were summarized in Fig. 2.

Effects of pretreatment with $H A$ on the cardiovascular effects of icv injection of NaHS

Fig. 3 presented the representative original tracings of the effect of prior application of vehicle (aCSF, $5 \mu \mathrm{l}, \mathrm{n}=5$ ) or the CBS inhibitor HA (0.7 mg, $\mathrm{n}=7$ ) on the BP and HR responses to icv injection of NaHS. Pretreatment with aCSF neither altered the basal BP (92 $\pm 4 \mathrm{mmHg}$ vs. $97 \pm 8 \mathrm{mmHg}, \mathrm{P}>0.05)$ and HR $(437 \pm 37$ vs. $446 \pm 41 \mathrm{bpm}, \mathrm{P}>0.05$ ) nor influenced the responses of $\mathrm{BP}$ (from $97 \pm 7$ to $63 \pm 13 \mathrm{mmHg}, P<0.05$ ) and $\mathrm{HR}$ (from $446 \pm 41$ to $416 \pm 36 \mathrm{bpm}, P<0.05$ ) to icv injection of NaHS (Fig. 4). Icv injection of HA produced a significant decrease in BP (from $93 \pm 3$ to $76 \pm 5 \mathrm{mmHg}, P<0.05$ ) but didn't influence HR (433 \pm 5 vs. $418 \pm 9$ bpm, $P>0.05)$. Prior icv injection of HA didn't alter the BP (aCSF pretreatment: $-28 \pm 12$ vs. HA pretreatment: $-21 \pm 9$ mmHg, $P>0.05$ ) or HR (aCSF pretreatment: $-30 \pm 10$ vs. HA pretreatment: $-45 \pm 28 \mathrm{bpm}, P>0.05$, Fig. 5) responses to icv NaHS. The influences of prior application of HA on the BP or HR response to NaHS were summarized in Fig. 5.
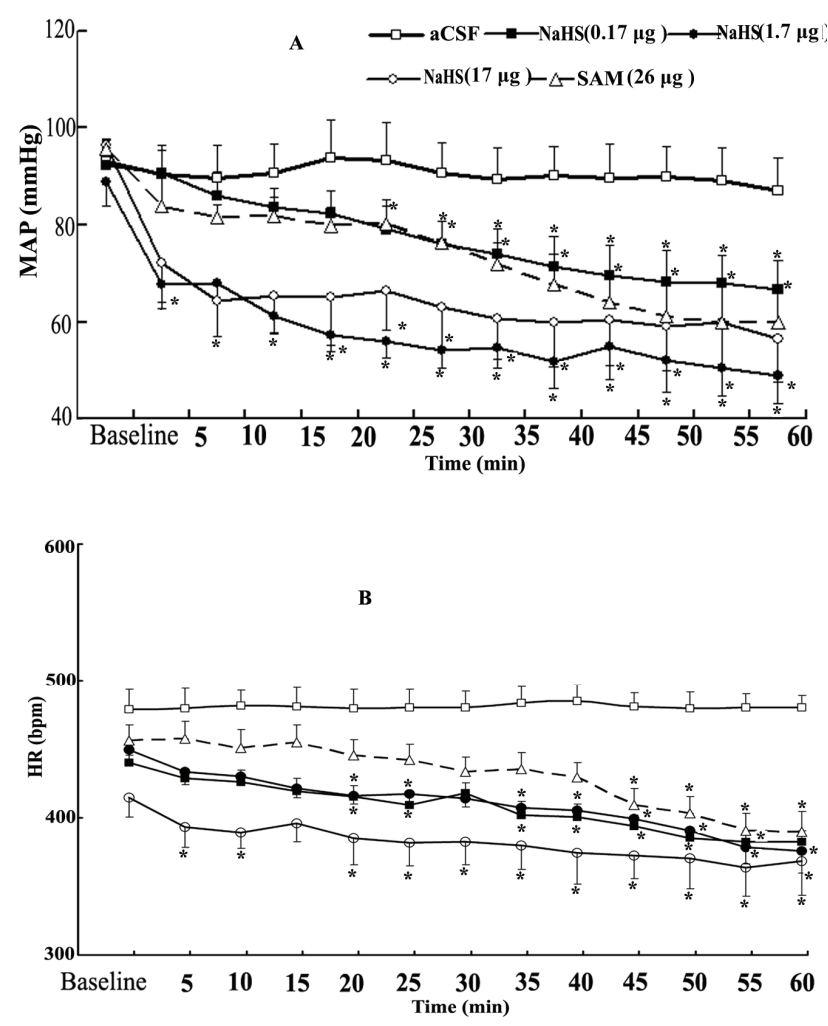

Fig. 2. The effects of icv injection of artificial cerebrospinal fluid (aCSF, $5 \mu \mathrm{l}$ ), hydrogen sulfide (NaHS, 0.17 17 $\mu \mathrm{g}$ ) or S-adenosyl-L-methionine (SAM, $26 \mu \mathrm{g}$ ) on blood pressure $(\mathbf{A})$ and heart rate $(B)$ of rats $(n=4-7)$. * $P<0.05$, compared with preinjection of aCSF, NaHS, or SAM by Student's $t$-test statistical test.

Effects of pretreatment with the $K_{A T P}$ channels blocker glibenclamide on the cardiovascular response to icv injection of NaHS

Fig. 4 presented the representative original tracings of the effect of prior application of vehicle (aCSF, $5 \mu \mathrm{l}, \mathrm{n}=5$ ) or the $\mathrm{K}_{\mathrm{ATP}}$ channels blocker glibenclamide $(0.5 \mu \mathrm{g}, \mathrm{n}=7)$ on the BP and HR responses to icv injection of NaHS. Icv injection of vehicle didn't alter the basal BP $(93 \pm 9$ vs. $93 \pm 11 \mathrm{mmHg}, P>0.05)$ and HR ( $465 \pm 28$ vs. $462 \pm 22 \mathrm{mmHg}, P>0.05$ ), but also didn't influence hypotension (from $93 \pm 11$ to $79 \pm 18 \mathrm{mmHg}$, $P<0.05$ ) and bradycardia (from $462 \pm 22$ vs. $410 \pm 49$, 

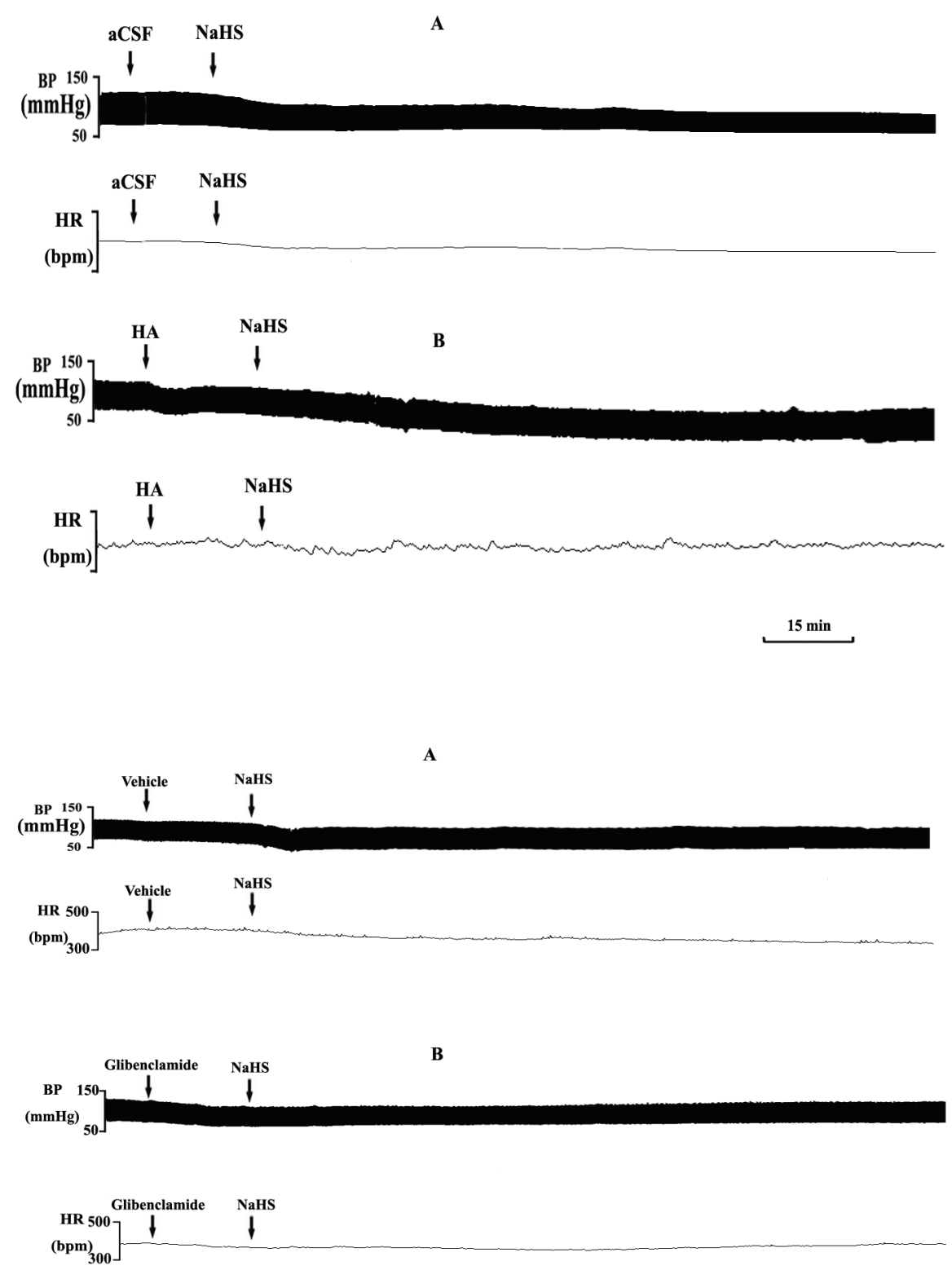

Fig. 3. The representative tracings showing the effects of prior administration of vehicle (aCSF, $5 \mu \mathrm{l}, \mathbf{A}$ ) or hydroxylamine (HA, $0.7 \mathrm{mg}, \mathbf{B}$ ) on blood pressure (BP) and heart rate (HR) response to icv application of hydrogen sulfide (NaHS, $1.7 \mu \mathrm{g}$ ) in rats. The arrow indicated the time point of prior injection of vehicle (aCSF) or HA. NaHS was injected after $10 \mathrm{~min}$.
Fig. 4. The representative tracings showing the effects of prior administration of vehicle (aCSF, $5 \mu \mathrm{l}, \mathbf{A}$ ) or glibenclamide $(0.5 \mu \mathrm{g}, \mathrm{B})$ on blood pressure (BP) and heart rate (HR) response to icv application of hydrogen sulfide (NaHS, $1.7 \mu \mathrm{g}$ ) in rats. The arrow indicated the time point of prior injection of vehicle (aCSF) or glibenclamide. NaHS was injected after $10 \mathrm{~min}$.
$P<0.05)$ of icv application of NaHS $(1.7 \mu \mathrm{g})$ on BP. Central application of glibenclamide $(0.5 \mu \mathrm{g}, \mathrm{n}=7)$ produced no significant influences on the basal BP (from $103 \pm 5$ to $99 \pm 5 \mathrm{mmHg}, P>0.05)$ and $\mathrm{HR}(437 \pm 39$ vs. $435 \pm 36 \mathrm{bpm}, P>0.05)$, but significantly decreased the hypotension $(-14 \pm 9$ vs. $-5 \pm 4 \mathrm{mmHg}, P<0.05)$ and bradycardia ( $-52 \pm 33$ vs. $18 \pm 27 \mathrm{bpm}, P<0.05)$ induced by icv injection of $1.7 \mu \mathrm{g}$ NaHS (Fig. 5).

\section{Discussion}

In the present study, our important findings were: 1. central application of the endogenous $\mathrm{H}_{2} \mathrm{~S}$ donor
NaHS or the activator of CBS SAM produced hypotension and bradycardia; and 2 . the central cardiovascular effects of endogenous $\mathrm{H}_{2} \mathrm{~S}$ were dependent on the $\mathrm{K}_{\text {ATP }}$ channel activation.

In the present study, we found that icv application of NaHS $(0.17 \sim 17 \mu \mathrm{g})$ produced a sustained and marked hypotension and bradycardia. It is known that the cerebral spinal fluid (CSF) of rat is about 250 $\mu 1$. The final concentration of $\mathrm{H}_{2} \mathrm{~S}$ in CSF in present study is about $40-400 \mu \mathrm{mol} / \mathrm{l}$, does not exceed twice of the physiological concentration level, under the lethal concentration of $\mathrm{H}_{2} \mathrm{~S}$ in the brain (Warenycia et al. 1989). 
TOP

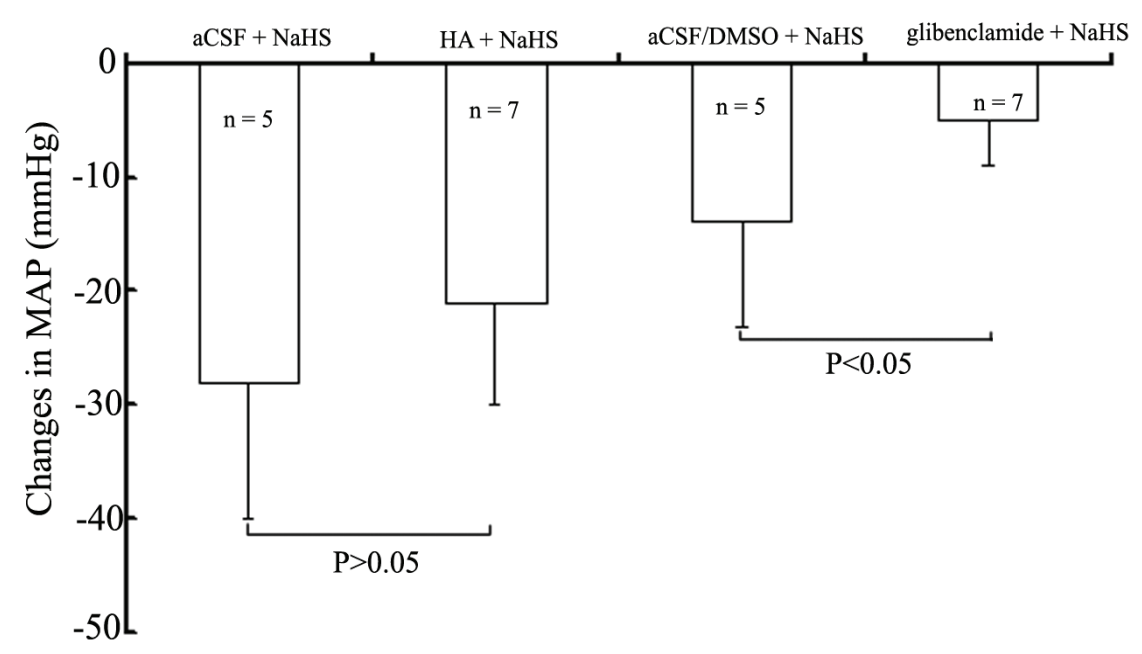

Fig. 5. Bar graphs showing the effects of pretreatment with hydroxylamine $(\mathrm{HA}, 0.7 \mathrm{mg})$ or glibenclamide $(0.5 \mu \mathrm{g})$ on blood pressure (BP) and heart rate (HR) response to icv injection of NaHS $(1.7 \mu \mathrm{g}) . \mathrm{aCSF}+\mathrm{NaHS}$ : pretreatment with aCSF; HA + NaHS: pretreatment with hydroxylamine (HA); aCSF/DMSO + NaHS: pretreatment with mix solution of aCSF and DMSO (the concentration of DMSO was not more than $1 \%$ ); glibenclamide + NaHS: pretreatment with glibenclamide. $P<0.05$, compared with pretreatment vehicle (aCSF, ANOVA test).

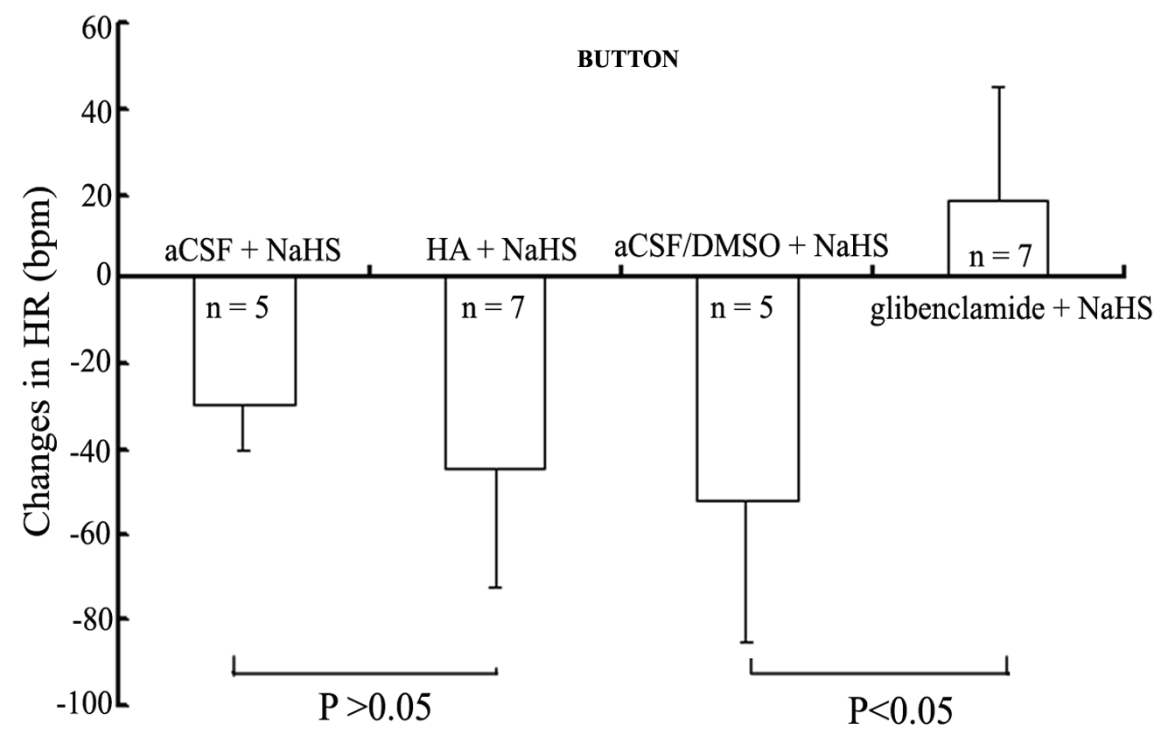

More recently, it is reported that the concentration of tissue free hydrogen sulfide is only on the order of $15 \mathrm{nM}$, which is very lower than the presently accepted values (Furne et al. 2008), implicating that $\mathrm{H}_{2} \mathrm{~S}$ might serve as an endogenously gaseous messenger in very low concentration. $\mathrm{H}_{2} \mathrm{~S}$ dissociates to $\mathrm{H}^{+}$and $\mathrm{HS}^{-}$in solution. In physiologic conditions $\left(37^{\circ} \mathrm{C}\right.$, $\mathrm{pH}$ 7.4), only a little of $\mathrm{H}_{2} \mathrm{~S}$ (less than one fifth) exists as the undissociated form $\left(\mathrm{H}_{2} \mathrm{~S}\right)$, and the remaining four fifths exist as $\mathrm{HS}^{-}$plus a trace of $\mathrm{S}^{2-}$ at equilibrium with $\mathrm{H}_{2} \mathrm{~S}$ (Dombkowski et al. 2004, Webb et al. 2008). Although which active form of $\mathrm{H}_{2} \mathrm{~S}\left(\mathrm{H}_{2} \mathrm{~S}, \mathrm{HS}^{-}\right.$, or $\mathrm{S}^{2-}$, the mix of free inorganic sulfides) has not been determined, Ondrias et al. (2008) assumed that $\mathrm{HS}^{-}$(but not $\mathrm{H}_{2} \mathrm{~S}$ or $\mathrm{S}^{2-}$ ) is probably the active form of ' $\mathrm{H}_{2} \mathrm{~S}$ ' because the effects of NaHS on stimulating NO release from NO donors depend on the $\mathrm{pH}$. The higher dose $(17 \mu \mathrm{g})$ produced obviously toxic responses because the rats died for respiratory inhibition if not artificial ventilation promptly. It is hypothesized that the hypotension and bradycardia of $\mathrm{H}_{2} \mathrm{~S}(0.17 \sim 17 \mu \mathrm{g})$ are the physiological responses rather than toxic responses. However, our results are different from the results reported by Ufnal et al. (2008). It may be due to following reasons: 1. In our study, the rats were anaesthetized; 2. NaHS was administrated by an bolus injection $(20 \mathrm{mM})$ in our study, while it was administrated by continuously infusion (100 400 nM of NaHS/h) in Ufnal's study (Ufnal et al. 2008). 3. The doses of NaHS used in Ufnal's study (100 400 nM of NaHS/h) were significantly lower than 
those in our present study. In a thesis, Huang et al. reported that electrophoresis NaHS $(-60 \mathrm{nA},-90 \mathrm{nA}$ or $-120 \mathrm{nA}$ ) produced exciting-inhibiting biphasic responses in presympathetic neurons in rats (Huang 2008). Based on their results, we supposed that $\mathrm{H}_{2} \mathrm{~S}$ probably produced different responses in $\mathrm{BP}$ of rats, low concentration mainly produced hypertension while high dose produced hypotension. Our study didn't found significant hypertension in any time point probably because of the differences in the way of administration and anesthetized rats.

Our conclusion is also supported by icv injection of CBS activator SAM. Previous studies have demonstrated that SAM is an allosteric regulator of CBS, which activates CBS by approximately two-fold (Finkelstein 2007, Abe and Kimura 1996). We found that central application of SAM $(26 \mu \mathrm{g})$ produced such a significant decrease in BP and HR as those of central application of NaHS, strongly supporting that central $\mathrm{H}_{2} \mathrm{~S}$ produces a decrease in $\mathrm{BP}$ and $\mathrm{HR}$ in anesthetized rats.

Besides, our study shows that HA, an inhibitor of CBS, significantly decreased basal BP but didn't influence basal HR. It has been reported that HA is a donor of NO. Central application of HA can efficiently decrease BP by increasing the central concentration of NO (Lin et al. 1999). Additionally, HA effectively inhibits the production of endogenous $\mathrm{H}_{2} \mathrm{~S}$ as an allosteric inhibitor of CBS (Abe and Kimura 1996, Han et al. 2005). However, in our study we observed that HA didn't influence the cardiovascular effects of central application of NaHS, suggesting that HA doesn't affect the conversion between $\mathrm{H}_{2} \mathrm{~S}$ and NaHS. Previous studies also indicate that the release of $\mathrm{NO}$ was stimulated by $\mathrm{NaHS}$ not only from NO donors but also from rat brain homogenate and from L1210 cells (Ondrias et al. 2008). This may be supported by numerous reports showing that ' $\mathrm{H}_{2} \mathrm{~S}$ ' shares many biological effects with NO (Cabrera and Bohr 1995). It is assumed that the hypotension and bradycardia induced by icv injection of NaHS probably be the consequence of increase in the release of NO in central system because icv injection of S-nitrosothiols, a donor of NO, produces the similar hypotension and bradycardia as NaHS. HA as a kind of donor of NO has been well accepted (Lin et al. 1999). In addition, HA can inhibit nitric oxide synthase (Abe and Kimura 1996, Han et al. 2005). In our present study, however, icv injection of HA, an inhibitor of nitric oxide, didn't alter the hypotension and bradycardia induced by icv injection of NaHS. The data shown above argue against the opinion that the cardiovascular functions of icv injection of NaHS might be the results of increase in the release of NO by $\mathrm{H}_{2} \mathrm{~S}$.

To address the question whether the cardiovascular effects of central $\mathrm{H}_{2} \mathrm{~S}$ are mediated by $\mathrm{K}_{\mathrm{ATP}}$ channels activation, the blocker of $\mathrm{K}_{\mathrm{ATP}}$ glibenclamide was applied to observe whether the cardiovascular effects of central $\mathrm{H}_{2} \mathrm{~S}$ is effectively attenuated by blocking of $\mathrm{K}_{\mathrm{ATP}}$ channel. Our data indicates that glibenclamide completely abolishes the hemodynamic effects induced by icv injection of NaHS. Hence, it suggests that the central hemodynamic effects of NaHS are mediated by $\mathrm{K}_{\mathrm{ATP}}$ channels activation. It has been reported that glibenclamide effectively antagonizes the depressor effects within posterior hypothalamus and vasorelaxation of smooth muscles (Geng et al. 2007, Dawe et al. 2008) as a selective blocker of $\mathrm{K}_{\mathrm{ATP}}$ channels. In our present study, we found that the cardiovascular effects of icv injection of NaHS were effectively antagonized by glibenclamide. However, we didn't know the exact role of $\mathrm{K}_{\mathrm{ATP}}$ channel activation in mediating central cardiovascular effects of $\mathrm{H}_{2} \mathrm{~S}$. In CNS, $\mathrm{K}_{\text {ATP }}$ channels consist of the Kir6.x potassium channel subunits and the sulfonylurea receptor subunits (Kang et al. 2004, Babenko et al. 1998), similar to those in heart and muscle (Liss and Roeper 2001). Kir6.x subunits belong to the inward rectifier potassium channel family, while SUR subunits belong to the ATP-binding cassette protein superfamily (Aguilar-Bryan and Bryan 1999). Previous studies show that the central $\mathrm{K}_{\mathrm{ATP}}$ channels, which play a vital role in glucose homeostasis, might be independent on cytosolic second messengers (Minami et al. 2003, Minami et al. 2004). Although the existence of $\mathrm{K}_{\mathrm{ATP}}$ channels in brainstem has been determined by previous studies (Ferreira et al. 2001, Dallaporta et al. 2000), the signaling pathway of $\mathrm{K}_{\mathrm{ATP}}$ involved in regulation of cardiovascular effects is not clear.

It has been well known that activation of $\mathrm{K}_{\mathrm{ATP}}$ channels is crucial to keep neuronal excitability in chemoreflex pathways in NTS (nucleus tractus solitarii, NTS) level (Zhang et al. 2008). However, whether the hypotension induced by central $\mathrm{H}_{2} \mathrm{~S}$ is dependent on chemoreflex are not clear. Because the cardiovascular responses to application of NaHS or SAM into LCV might be mediated by integrative interactions between different central cardiovascular regions, no evidence is available to determine which regions are involved in mediating the cardiovascular functions of central $\mathrm{H}_{2} \mathrm{~S}$. Perhaps the reduction of the release of several 
neurotransmitters, including excitatory transmitter glutamate (Soundarapandian et al. 2007) and inhibitory transmitter GABA (Avshalumov and Rice 2003) as well as the functions of NMDA receptors by activation of $\mathrm{K}_{\mathrm{ATP}}$ channels is involved in the hypotension of central $\mathrm{H}_{2} \mathrm{~S}$. The exact cardiovascular mechanism of central $\mathrm{H}_{2} \mathrm{~S}$ needs to be further determined.

\section{Conflict of Interest}

There is no conflict of interest.

\section{Acknowledgements}

This work was supported by the National Natural Science Foundation of China (No. 30700266). We thank Prof. Ya-Na Bai for her expert statistical assistance.

\section{References}

ABE K, KIMURA H: The possible role of hydrogen sulfide as an endogenous neuromodulator. J Neurosci 16: 1066$1071,1996$.

AGUILAR-BRYAN L, BRYAN J: Molecular biology of adenosine triphosphate-sensitive potassium channels. Endocr Rev 20: 101-135, 1999.

AVSHALUMOV MV, RICE ME: Activation of ATP-sensitive $\mathrm{K}^{+}\left(\mathrm{K}(\mathrm{ATP})\right.$ ) channels by $\mathrm{H}_{2} \mathrm{O}_{2}$ underlies glutamatedependent inhibition of striatal dopamine release. Proc Natl Acad Sci U S A 100: 11729-11734, 2003.

BABENKO AP, AGUILAR-BRYAN L, BRYAN J: A view of sur/K $\mathrm{K}_{\mathrm{IR}}$ 6.X, $\mathrm{K}_{\mathrm{ATP}}$ channels. Annu Rev Physiol 60: 667$687,1998$.

BEAUCHAMP RO Jr, BUS JS, POPP JA, BOREIKO CJ, ANDJELKOVICH DA: A critical review of the literature on hydrogen sulfide toxicity. Crit Rev Toxicol 13: 25-97, 1984.

BELTOWSKI J: Hydrogen sulfide as a biologically active mediator in the cardiovascular system. (in Polish) Postepy Hig Med Dosw (Online) 58: 285-291, 2004.

BOEHNING D, SNYDER SH: Novel neural modulators. Annu Rev Neurosci 26: 105-131, 2003.

CABRERA C, BOHR D: The role of nitric oxide in the central control of blood pressure. Biochem Biophys Res Commun 206: 77-81, 1995.

CHEN CQ, XIN H, ZHU YZ: Hydrogen sulfide: third gaseous transmitter, but with great pharmacological potential. Acta Pharmacol Sin 28: 1709-1716, 2007.

DALLAPORTA M, PERRIN J, ORSINI JC: Involvement of adenosine triphosphate-sensitive $\mathrm{K}^{+}$channels in glucosesensing in the rat solitary tract nucleus. Neurosci Lett 278: 77-80, 2000.

DAWE GS, HAN SP, BIAN JS, MOORE PK: Hydrogen sulphide in the hypothalamus causes an ATP-sensitive K ${ }^{+}$ channel-dependent decrease in blood pressure in freely moving rats. Neuroscience 152: 169-177, 2008.

DISTRUTTI E, SEDIARI L, MENCARELLI A, RENGA B, ORLANDI S, ANTONELLI E, ROVIEZZO F, MORELLI A, CIRINO G, WALLACE JL, FIORUCCI S: Evidence that hydrogen sulfide exerts antinociceptive effects in the gastrointestinal tract by activating $\mathrm{K}_{\mathrm{ATP}}$ channels. J Pharmacol Exp Ther 316: 325-335, 2006.

DOMBKOWSKI RA, RUSSELL MJ, OLSON KR: Hydrogen sulfide as an endogenous regulator of vascular smooth muscle tone in trout. Am J Physiol Regul Integr Comp Physiol 286: R678-R685, 2004.

ETO K, OGASAWARA M, UMEMURA K, NAGAI Y, KIMURA H: Hydrogen sulfide is produced in response to neuronal excitation. $J$ Neurosci 22: 3386-3391, 2002.

FERREIRA M Jr., BROWNING KN, SAHIBZADA N, VERBALIS JG, GILLIS RA, TRAVAGLI RA: Glucose effects on gastric motility and tone evoked from the rat dorsal vagal complex. J Physiol 536: 141-152, 2001.

FINKELSTEIN JD: Metabolic regulatory properties of S-adenosylmethionine and S-adenosylhomocysteine. Clin Chem Lab Med 45: 1694-1699, 2007.

FURNE J, SAEED A, LEVITT MD: Whole tissue hydrogen sulfide concentrations are orders of magnitude lower than presently accepted values Am J Physiol Regul Integr Comp Physiol 295: R1479-R1485, 2008.

GALlEGO D, CLAVE P, DONOVAN J, RAHMATI R, GRUNDY D, JIMENEZ M, BEYAK MJ: The gaseous mediator, hydrogen sulphide, inhibits in vitro motor patterns in the human, rat and mouse colon and jejunum. Neurogastroenterol Motil 20: 1306-1316, 2008. 
GENG B, CUI Y, ZHAO J, YU F, ZHU Y, XU G, ZHANG Z, TANG C, DU J: Hydrogen sulfide downregulates the aortic L-arginine/nitric oxide pathway in rats. Am J Physiol Regul Integr Comp Physiol 293: R1608-R1618, 2007.

HAN Y, QIN J, CHANG X, YANG Z, TANG X, DU J: Hydrogen sulfide may improve the hippocampal damage induced by recurrent febrile seizures in rats. Biochem Biophys Res Commun 327: 431-436, 2005.

HOSOKI R, MATSUKI N, KIMURA H: The possible role of hydrogen sulfide as an endogenous smooth muscle relaxant in synergy with nitric oxide. Biochem Biophys Res Commun 237: 527-531, 1997.

HUANG Y: Hydrogen Sulfide Affects Presympathetic Neurons in RVLM in Rats. Second Military Medical University, Shanghai, 2008.

KANG Y, LEUNG YM, MANNING-FOX JE, XIA F, XIE H, SHEU L, TSUSHIMA RG, LIGHT PE, GAISANO HY: Syntaxin-1A inhibits cardiac $\mathrm{K}_{\mathrm{ATP}}$ channels by its actions on nucleotide binding folds 1 and 2 of sulfonylurea receptor 2A. J Biol Chem 279: 47125-47131, 2004.

KIMURA H: Hydrogen sulfide as a neuromodulator. Mol Neurobiol 26: 13-19, 2002.

LAGGNER H, HERMANN M, ESTERBAUER H, MUELLNER MK, EXNER M, GMEINER BM, KAPIOTIS S: The novel gaseous vasorelaxant hydrogen sulfide inhibits angiotensin-converting enzyme activity of endothelial cells. J Hypertens 25: 2100-2104, 2007.

LIN MT, PAN SP, LIN JH, YANG YL: Central control of blood pressure by nitrergic mechanisms in organum vasculosum laminae terminalis of rat brain. Br J Pharmacol 127: 1511-1517, 1999.

LISS B, ROEPER J: Molecular physiology of neuronal K-ATP channels (review). Mol Membr Biol 18: 117-127, 2001.

LOWICKA E, BELTOWSKI J: Hydrogen sulfide $\left(\mathrm{H}_{2} \mathrm{~S}\right)$ - the third gas of interest for pharmacologists. Pharmacol Rep 59: 4-24, 2007.

LU Y, WANG LG, LIAO Z, TANG CS, WANG WZ, YUAN WJ: Cardiovascular effects of centrally applied endothelin-1 1-31 and its relationship to endothelin-1 1-21 in rats. Auton Neurosci 133: 146-152, 2007.

LU Y, WANG WZ, LIAO Z, YAN XH, TANG CS, YUAN WJ: Blood pressure responses of endothelin-1 1-31 within the rostral ventrolateral medulla through conversion to endothelin-1 1-21. J Cardiovasc Pharmacol 46: 823$829,2005$.

MINAMI K, MIKI T, KADOWAKI T, SEINO S: Roles of ATP-sensitive $\mathrm{K}^{+}$channels as metabolic sensors: studies of Kir6.x null mice Diabetes 53 (Suppl 3): S176-S180, 2004.

MINAMI K, MORITA M, SARAYA A, YANO H, TERAUCHI Y, MIKI T, KURIYAMA T, KADOWAKI T, SEINO S: ATP-sensitive $\mathrm{K}^{+}$channel-mediated glucose uptake is independent of IRS-1/phosphatidylinositol 3kinase signaling. Am J Physiol Endocrinol Metab 285: E1289-E1296, 2003.

NISHIMURA M, NANBU A, SAKAMOTO M, NAKANISHI T, TAKAHASHI H, YOSHIMURA M: Role of cerebral ATP-sensitive $\mathrm{K}^{+}$channels in arterial pressure regulation during acute cerebral ischaemia in SHR and WKY rats. Clin Exp Pharmacol Physiol Suppl 22: S70-S72, 1995a.

NISHIMURA M, TAKAHASHI H, NANBU A, SAKAMOTO M, NAKANISHI T, YOSHIMURA M: Cerebral ATPsensitive potassium channels during acute reduction of carotid blood flow. Hypertension 25: 1069-1074, 1995b.

ONDRIAS K, STASKO A, CACANYIOVA S, SULOVA Z, KRIZANOVA O, KRISTEK F, MALEKOVA L, KNEZL V, BREIER A: $\mathrm{H}_{2} \mathrm{~S}$ and $\mathrm{HS}^{-}$donor NaHS releases nitric oxide from nitrosothiols, metal nitrosyl complex, brain homogenate and murine L1210 leukaemia cells. Pflugers Arch 457: 271-279, 2008.

REIFFENSTEIN RJ, HULBERT WC, ROTH SH: Toxicology of hydrogen sulfide. Annu Rev Pharmacol Toxicol 32: 109-134, 1992.

SOUNDARAPANDIAN MM, WU D, ZHONG X, PETRALIA RS, PENG L, TU W, LU Y: Expression of functional Kir6.1 channels regulates glutamate release at CA3 synapses in generation of epileptic form of seizures. J Neurochem 103: 1982-1988, 2007.

TANG G, WU L, LIANG W, WANG R: Direct stimulation of K(ATP) channels by exogenous and endogenous hydrogen sulfide in vascular smooth muscle cells. Mol Pharmacol 68: 1757-1764, 2005.

TEAGUE B, ASIEDU S, MOORE PK: The smooth muscle relaxant effect of hydrogen sulphide in vitro: evidence for a physiological role to control intestinal contractility. Br J Pharmacol 137: 139-145, 2002. 
UFNAL M, SIKORA M, DUDEK M: Exogenous hydrogen sulfide produces hemodynamic effects by triggering central neuroregulatory mechanisms. Acta Neurobiol Exp (Wars) 68: 382-388, 2008.

WANG R: Two's company, three's a crowd: can $\mathrm{H}_{2} \mathrm{~S}$ be the third endogenous gaseous transmitter? FASEB $J$ 16: 1792$1798,2002$.

WANG R: The gasotransmitter role of hydrogen sulfide. Antioxid Redox Signal 5: 493-501, 2003.

WARENYCIA MW, GOODWIN LR, BENISHIN CG, REIFFENSTEIN RJ, FRANCOM DM, TAYLOR JD, DIEKEN FP: Acute hydrogen sulfide poisoning. Demonstration of selective uptake of sulfide by the brainstem by measurement of brain sulfide levels. Biochem Pharmacol 38: 973-981, 1989.

WEBB GD, LIM LH, OH VM, YEO SB, CHEONG YP, ALI MY, EL OAKLEY R, LEE CN, WONG PS, CALEB MG, SALTO-TELLEZ M, BHATIA M, CHAN ES, TAYLOR EA, MOORE PK: Contractile and vasorelaxant effects of hydrogen sulfide and its biosynthesis in the human internal mammary artery. J Pharmacol Exp Ther 324: 876-882, 2008.

YANG W, YANG G, JIA X, WU L, WANG R: Activation of $\mathrm{K}_{\text {ATP }}$ channels by $\mathrm{H}_{2} \mathrm{~S}$ in rat insulin-secreting cells and the underlying mechanisms. J Physiol 569: 519-531, 2005.

ZHANG W, CARRENO FR, CUNNINGHAM JT, MIFFLIN SW: Chronic sustained and intermittent hypoxia reduce function of ATP-sensitive potassium channels in nucleus of the solitary tract. Am J Physiol Regul Integr Comp Physiol 295: R1555-R1562, 2008.

ZHAO W, ZHANG J, LU Y, WANG R: The vasorelaxant effect of $\mathrm{H}_{2} \mathrm{~S}$ as a novel endogenous gaseous $\mathrm{K}_{\mathrm{ATP}}$ channel opener. EMBO J 20: 6008-6016, 2001. 